\title{
ФОРМУВАННЯ ПРОФЕСІЙНОЇ КОМПЕТЕНТНОСТІ МЕДИЧНОЇ СЕСТРИ 3 ПИТАНЬ ПІДГОТОВКИ ПОДРУЖНІХ ПАР ДО ПАРТНЕРСЬКИХ ПОЛОГІВ
}

\author{
Л. М. Маланчук, О. В. Лісіна, С. Л. Маланчук, В. М. Мартинюк, \\ А. С. Маланчук, Т. А. Небесьо \\ Тернопільський національний медичний університет \\ імені І. Я. Горбачевського МОЗ Украӥни
}

Стаття присвячена аспектам формування професійної компетентності медичних сестер у питаннях родиноорієнтованих технологій.

\section{FORMATION OF PROFESSIONAL NURSES COMPETENCES IN PREPARING MARRIED COUPLES FOR THE PARTNER CHILDBIRTH}

\author{
L. M. Malanchuk, O. V. Lisina, S. L. Malanchuk, V. M. Martunyk, \\ A. S. Malanchuk, T. A. Nebeso

\section{Horbachevsky Ternopil National Medical University}

The article is devoted to aspects of formation professional competence of nurses in issues of family-oriented technologies.

Вступ. Поняття «компетентність», «професійна компетентність» у широкому розумінні розглядаються як ступінь соціальної й психологічної зрілості людини в сенсі особистого психічного розвитку і готовності до різного виду діяльності з метою успішного інтегрування у суспільстві. Міра інтегрованості людини в суспільну діяльність розцінюється як «компетенція» у вузькому значенні.

Професійна компетентність медичної сестри базується на загальних та спеціальних знаннях та уміннях, які $є$ необхідними для здійснення професійної діяльності. Спілкування $\epsilon$ головним інструментом професійної діяльності медичних сестер, кроком уперед на шляху формування мовно-професійної компетенції майбутніх фахівців [4].

Формування професійної компетентності медичної сестри вирішує питання її самостійності в отриманні та аналізі інформації, вмінні знаходити шляхи раціонального вирішення проблем пацієнтів та надавати фахову допомогу. Саме такі якості медичної сестри «новітнього взірця», як автономність, кваліфікованість, мобільність, цілеспрямованість, дозво- ляють отримати найкращі результати у професійній діяльності [6].

Під час надання медичних послуг медична сестра повинна вдало використовувати соціально-особистісні, загальнонаукові, інструментальні, загальнопрофесійні та спеціалізовані професійні компетенції. Регламентуючі документи стандартів сестринської допомоги потрібно адекватно редагувати до вимог сьогодення та умов виконання професійної діяльності у кожній галузі медицини [4].

Впровадження родиноорієнтованих технологій в акушерську практику, активне залучення ланки первинної медичної допомоги до питань ведення вагітності та пологів дозволять вирішити цілу низку питань з профілактики акушерських та перинатальних ускладнень, які особливо гостро звучать в умовах зниження народжуваності та збільшення показника смертності в Україні [5].

Роль медичної сестри у подоланні інерційного процесу суспільного усвідомлення необхідності впровадження партнерських пологів полягає у повсякденній кропіткій роботі з подружніми парами, які

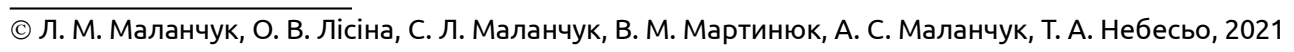


планують вагітність. Без сумніву такий вид роботи вимагає впровадження певних реформ і потребує, крім організаційно-законодавчого та фінансового забезпечення, самовіддану, творчу роботу медичного персоналу [3].

В основі успішного існування школи відповідального батьківства та реалізації поставленої мети навчання $\epsilon$ два ключових моменти: з одного боку, професіонал своєї справи (донор), з іншого - свідомий учасник (реципієнт). Обидва гравці виконують важливу роль і кінцевий результат залежить від активності обох сторін.

Основна частина. За сучасним науковим визначенням, комунікація, від лат. communiko - «спілкуюсь з кимсь», є процесом обміну інформацією, а інтеракція, у перекладі з англійської мови interaction «взаємодія» - сприймання людини людиною. У конкретних умовах і ситуаціях медична сестра, використовуючи знання та комунікативні навички, впливає на результат лікувально-діагностичного процесу. Задовільний результат досягається через обмін думками, оцінками, почуттями, волевиявлення з метою інформування, емоційний вплив, спонукання до спільної діяльності тощо [2].

У психології виділяють такі функції спілкування:

- інформаційно-комунікативну - передбачає передавання та приймання не лише готової інформації, а й такої, що формується, розвивається, а також передавання та приймання значень;

- регуляторно-комунікативну - коли спілкування регулює поведінку людей та їхню спільну діяльність, а також способи впливу один на одного: переконання, навіювання, наслідування та ін.;

- афективно-комунікативну - коли йдеться про те, що розмаїття людських емоцій виникає й проявляється саме під час спілкування.

Підготовка до такого виду діяльності повинна розпочинатися ще із студентських лав. На такі заняття потрібно відводити певну кількість годин відповідно до навчальної програми. Так, розбираючи тему фізіологічної вагітності, пологів, післяпологового періодів, варто приділяти увагу комунікативним навичкам майбутніх медичних сестер. Вони повинні бути обізнані з теоретичних питань перинатальних технологій, а також вдало поєднувати їх із практичною діяльністю, спостерігаючи за перебігом нормальної вагітності. У їхнє завдання входить вирішування складних деонтологічних завдань, які пов'язані з підтримкою родиноорієнтованих технологій. Підго- товка партнерських пар до пологів та догляду за новонародженим є кропіткою і нелегкою роботою [3].

Працюючи із дорослою аудиторією, необхідно пам'ятати про певні особливості проведення навчання:

- наявність самоусвідомленого бажання пар навчатися новим родиноорієнтованим технологіям;

- мета кожного наступного заняття повинна задовольняти нагальні потреби у слухачів;

- інтерактивні технології в процесі розбору теоретичного матеріалу допомагають усім учасникам процесу навчання краще опанувати знання.

Покращити результат навчання допомагають:

- наявність реального досвіду тренера з теми викладання;

- розвинене рефлекторне спостереження;

- наявна абстрактна концептуалізація;

- відсутність боязні активного експериментування.

В основі успішного навчання $\epsilon$ два ключових моменти: з одного боку, професіонал своєї справи (донор), з іншого - свідомий учасник (реципієнт). Обидва гравці виконують важливу роль і кінцевий результат залежить від активності обох сторін. Якщо сильні сторони «донора» проявляються в його тренерських здібностях, то «реципієнту» належить активно поглинати та трансформувати корисну інформацію.

Найкращим стимулом до навчання $є$ мотиваційна складова у ії учасників. Тому дуже важливо вже з перших занять активізувати шляхи розвитку емоційних відчуттів слухачів. Спілкування та вільний обмін інформацією - це серцевина всіх тренінгів та розвитку людських ресурсів. Використання різних методів та технік навчання допомагає розвинути активну комунікацію, уникнути пасивного слухання, подолати конфронтацію і розвинути емпатію. Обов'язковою складовою на всіх заняттях $є$ зворотний зв'язок в інформаційному просторі між учасниками події та неупереджене ставлення до різних думок.

Кожна лекція повинна мати конкретну мету та завдання, які потрібно розібрати в процесі навчання. Презентації, відео, ілюстрації, кейс-завдання, рольові ігри, групові обговорення - все це допомагає подолати бар'єр сприйняття між учасниками події. Особливу увагу необхідно приділяти роботі з оволодіння практичними навичками зменшення відчуття болю при пологах: самомасажу, дихальним вправам, релаксації тощо. Отож, без відповідних професійних 
компетентностей медичної сестри, успішне впровадження партнерських пологів неможливе.

Зокрема, студенти III курсу Подільського медичного фахового коледжу в рамках тижня «Репродуктивне здоров'я» та реалізації програми «Healthy Challenge» щороку проводять захід, який присвячений школі відповідального батьківства. Кінцеві цілі навчання передбачають поглиблення знань студентів щодо фізіологічних змін в організмі жінки під час вагітності та в післяпологовий період, а також набуття практично орієнтованих навичок із методології ефективного впровадження родиноорієнтованих технологій.

Програма заходу презентувалася виступами учасників семінару на різні теми:

1. Фізіологічні та психологічні зміни в організмі жінки під час вагітності, особливості партнерської підтримки.

2. Харчування та здоровий спосіб життя. Гігієна під час вагітності. Підготовка до партнерських пологів.

3. Принципи роботи у школі відповідального батьківства.

4. Фізіологічний післяпологовий період. Роль батьків у виходжуванні малюка.

Під час активної дискусії зроблено акцент на визначенні поняття «репродуктивне здоров'я». Ре-

\section{СПИСОК ЛІТЕРАТУРИ}

1. Права жінки у пологах та їх реалізація в Україні : інформаційна збірка «Природні Права Україна». - К., 2018. - 52 c.

2. Божук Б. С. Гестаційна домінанта як маркер у визначенні становлення материнської сфери / Б. С. Божук // Український науково-медичний молодіжний журнал. 2012. - № 3. - С. 100-102.

3. Вдовиченко С. Ю. Навчальні аспекти підготовки лікарів до проведення партнерських пологів / С. Ю. Вдовиченко // Збірник наукових праць співробітників НМАПО імені П. Л. Шупика : тези матеріалів науково- продуктивне здоров'я - це стан повного фізичного, розумового і соціального благополуччя, що характеризує здатність людей до зачаття і народження дітей, можливість сексуальних відносин без загрози захворювань, що передаються статевим шляхом, гарантію безпеки вагітності, пологів, виживання і здоров'я дитини, благополуччя матері, можливість планування наступних вагітностей, в тому числі й запобігання небажаній вагітності [1].

Турбота про збереження репродуктивного здоров'я також включає і сексуальне здоров'я, метою якого $є$ поліпшення життя та міжособистісних відносин, а не тільки консультації та лікування, пов'язані з репродукцією і інфекціями, що передаються статевим шляхом. Кожна вагітність повинна бути бажаною, а батьки майбутньої дитини - здоровими.

Висновки. Структурними складовими професійної компетентності медичної сестри $є$ усі знання, уміння та навички, які отримані нею у процесі теоретичного навчання, практичної діяльності та повинні стати основою висококваліфікованої роботи. Сучасна підготовка медичних сестер повинна передбачати теоретичну і практичну базу для розвитку ключових професійних компетентностей з питань відповідального батьківства та широко використовувати мотиваційну складову для досягнення кінцевої мети щасливого батьківства.

практичного семінару з міжнародною участю «Здоров'я матері, плода та новонародженого в Україні», 14 листоп. 2014 р., м. Київ. - К., 2014. - Вип. 23, кн. 6, ч. 2. - С. 308.

4. Губенко І. Я. Медсестринський процес / І. Я. Губенко, О. Т. Шевченко, В. Г. Апшай. - К. : Здоров'я, 2001. - 207 с.

5. Добряков И. В. Перинатальная психология / И. В. Добряков. - СПб. : Питер, 2010. - 272 с.

6. Кудрявцева Т. О. Сестринський процес: етапи, зміст, документація / Т. О. Кудрявцева. - К., 2001. - 95 с.

Отримано 14.01.21 